\title{
Ewangelik reformowany we wspólnocie Kościoła
}

\section{Zbór, czyli wspólnota}

Biorąc do ręki książkę lub artykuł poświęcony reformacji, możemy często spotkać się z praktyką określania mianem z b o ru budynków kościelnych użytkowanych przez ewangelików ${ }^{1}$. Utożsamienie zboru z budynkiem jest tak bardzo rozpowszechnione w literaturze przedmiotu, iż niektórzy ewangelicy machają na to ręką, nie mając już ochoty na nieustanne prostowanie owego nieporozumienia. Autor niniejszego tekstu jest jednak zdania, że doniosłość teologiczna słowa „zbór” jest na tyle duża, iż nie można przechodzić obojętnie nad stawianiem znaku równości pomiędzy zborem a budynkiem kościelnym, termin ten jest bowiem jednym z kluczy do właściwego rozumienia eklezjologii ewangelickiej i samoświadomości ewangelika reformowanego. Słowo „zbór”, obok takich haseł jak na przykład sola Scriptura, sola gratia, sola fide, zostało wypisane na sztandarach szesnastowiecznej reformacji, stając się rodzajem deklaracji eklezjologicznej i programem odnowy Kościoła. Profesor Katarzyna Meller trafnie zauważyła, że w czasach reformacji uaktywniło się ono „w znaczeniu, jakie podkreślić chcieli protestanci w swo-

1 Por. R. Leszczyński (sr), Kłopoty z Mikołajem Rejem, w: tenże, Pisma polemiczne, Warszawa 2011, s. 43-44. 
im rozumieniu Kościoła jako wspólnoty, congregatio sanctorum lub communio praedestinatorum. Słowo zbór w swym głębokim znaczeniu i w praktyce językowej miało moc polemiczną i moc wyznaniowego manifestu. Głosiło potrzebę odrzucenia tego, co w zastanym Kościele - hierarchicznej instytucji zbawienia kierowanej przez papieża - sprzeczne było z biblijną ideą ciała Kościoła, którego członkami są wszyscy chrześcijanie, a głową jest Chrystus. Biblijna metafora mówiła o Kościele duchowym, złożonym z ludzi odrodzonych dzięki wierze i zbawionych przez Chrystusa Zbawiciela. Było to odnowione w reformacyjnym sensie organiczne pojmowanie wspólnoty spojonej wiarą jako całości, w której wzajemne właściwe relacje poszczególnych części są równoważone i współodpowiedzialne za toczące się w Kościele naturalne procesy"2.

Jak wynika z zacytowanego fragmentu, zbór to bynajmniej nie budynek kościelny, ale wspólnota, zgromadzenie, zebranie, społeczność, zbiór osób wierzących w Chrystusa. W okresie narastającego sporu pomiędzy zwolennikami reformacji protestanckiej a Kościołem rzymskokatolickim oraz postępującej konfesjonalizacji teologii Kościołów zachodnich, pojęcie „zbór” było przeciwstawiane przez ewangelików instytucjonalnemu pojmowaniu Kościoła, które szczególnie wyraźnie ujawniło się w eklezjologii jezuity Roberta Bellarmina ${ }^{3}$. W kontrze do owych wyobrażeń (skorygowanych przez Sobór Watykański II) ${ }^{4}$, ewan-

2 K. Meller, Wielowyznaniowość jako czynnik wspólnototwórczy w Polsce XVI wieku, w: Humanizm polski i wspólnoty. Naród - społeczeństwo - państwo - Europa, red. M. Cieński, Warszawa 2010, s. 185 (wyróżnienia w oryginale).

3 Por. A.A. Napiórkowski, Koncepcje Kościoła i ich wpływ na stan mariologii i maryjności, w: Kościót i Maryja, red. A.A. Napiórkowski, Kraków 2020, s. 315.

4 Por. Porównanie wyznań rzymskokatolickiego, prawosławnego, ewangelicko-augsburskiego, ewangelicko-reformowanego, red. E. Jóźwiak, Warszawa 2014, s. 31. Wydane przez Kościół Ewangelicko-Reformowany w RP Porównanie wyznań zawiera teksty teologów reprezentujących wyznania 
gelicy wyznania helweckiego rozwijali wspólnotową koncepcję Kościoła, w której pojęcie zboru, czyli społeczności ludzi wierzących, odgrywało zasadniczą rolę, stojąc u podstaw reformowanej refleksji eklezjologicznej.

Z powyższych rozważań wypływa konkluzja, że termin „zbór” stanowi odpowiednik słowa ekklesia. Współczesny teolog ewangelicko-reformowany Karl Barth wyjaśniał znaczenie owego greckiego wyrazu następująco: „ekklesia znaczy niewątpliwie wspólnotę, zbór, zejście się, następujące w wyniku zawezwania - zgromadzenie ludowe, zbierające się na wołanie posłańca czy też na dźwięk trąbki herolda. Wspólnota jest zejściem się tych, którzy przez Ducha Świętego należą do Jezusa Chrystusa. [...] Ma ona miejsce tam, gdzie ludzie przez Ducha Świętego wezwani są do uczestniczenia w słowie i dziele Chrystusa. To szczególne przynależenie znajduje swój odpowiednik na płaszczyźnie horyzontalnej w należeniu tych ludzi wzajem do siebie. Wylanie Ducha Świętego bezpośrednio oddziałuje na ich zejście się. [...] Przez to, że ludzie tu i tam gromadzą się w Duchu Świętym, powstaje tu i tam widzialna wspólnota chrześcijańska"5. Zdaniem Bartha termin „zbór” lepiej oddaje wspólnotowy charakter społeczności ludzi wierzących w Chrystusa niż wyraz „Kościół” (Kirche), który obciążony jest znaczeniem instytucjonalnym, dlatego słusznie byłoby całkowicie poniechać używania tego słowa na rzecz pierwszego $z$ tych określeń ${ }^{6}$.

$Z$ wypowiedzi Bartha wynika, że gdy ewangelik reformowany mówi, iż należy do takiego a takiego zboru, to ogłasza w ten sposób, iż jest uczestnikiem konkretnej wspólnoty ludzkiej wie-

chrześcijańskie wymienione w tytule książki. Część poświęconą teologii rzymskokatolickiej przygotował ks. prof. Andrzej Zuberbier, a konsultacji przy drugim wydaniu opracowania udzielił ks. prof. Zygfryd Glazer.

5 K. Barth, Dogmatyka w zarysie, tłum. I. Nowicka, Warszawa 1994, s. 132.

6 Por. tamże. 
rzącej w Chrystusa jako swego Zbawiciela, czyli zgromadzenia osób wybranych, zbawionych i uświęconych przez Syna Bożego, wezwanych do Chrystusa przez Ducha Świętego. Należy też zauważyć, że gdy ewangelik reformowany oznajmia, iż jest członkiem danego zboru, to wyznaje przy tym, że należy do Kościoła powszechnego, gdyż poszczególne zbory są cząstkami Zboru powszechnego, a więc częścią Kościoła katolickiego, który jest zborem zborów (zbiorem zbiorów) i wspólnotą wspólnot. Kościół powszechny opiera się więc na lokalnych zborach (zgromadzeniach), stanowiąc niejako ich rozszerzenie.

Fakt przynależności do zboru kształtuje samoświadomość ewangelika reformowanego, wyznacza jego miejsce w lokalnej gminie chrześcijańskiej i w Kościele powszechnym, a także formuje jego spojrzenie na Ecclesia catholica, będącą dla niego w pierwszym rzędzie wspólnotą wierzących, a dopiero na znacznie dalszym miejscu instytucją i organizacją religijną. Uczestnictwo w określonym zborze jest więc podstawą życia duchowego wyznawcy ewangelicyzmu konfesji helweckiej i zasadniczym punktem odniesienia dla jego poglądów eklezjologicznych (teologicznych).

\section{Kościół (zbór) jako wspólnota wybranych}

Jedną z zasadniczych cech Kościoła jest jego dwoisty i dialektyczny charakter, wspólnota kościelna jest bowiem z jednej strony tworem ludzkim, atoli z drugiej dziełem Boskim. Zachodzi więc $\mathrm{w}$ niej spotkanie wymiaru wertykalnego $\mathrm{z}$ horyzontalnym, wieczności z doczesnością. Ewangelik reformowany w owym dialektycznym napięciu mocniej akcentuje pierwiastek boski, gdyż jest przekonany, że Kościół nie zaistniałby bez inicjatywy ze strony Boga. Co prawda, z jednej strony Bóg tworzy Kościół dla ludzi i ze względu na ludzi, dlatego są oni niezbędni do jego istnienia, z drugiej wszakże - ludzie nigdy nie znaleźliby się we 
wspólnocie Kościoła (zboru), gdyby nie zostali zaproszeni do niej przez Boga. Wyznawca ewangelicyzmu nurtu helweckiego twierdzi zatem, że do Kościoła zostajemy powołani na mocy odwiecznej decyzji Boga, w której Stwórca wybiera ludzi do wspólnoty ze sobą. Innymi słowy, Kościół to communio praedestinato$\mathrm{rum}^{7}$, ponieważ wspólnota kościelna jest inicjowana za sprawą aktu boskiej elekcji, w którym Bóg wskazuje swoich wybranych. Działo się tak w czasach Starego Przymierza, gdy Bóg wybrał do społeczności ze sobą naród żydowski (por. Pwt 4,20.37; Pwt 6,6; 14,2; Ps 105,43; 106,5; Iz 43,20-21; 45,4; 65,9; Rz 11,28), jak i w czasach Nowego Testamentu, w których uczynił On swoim wybranym ludem także wierzących w Niego pogan (por. Mt 24,22.24.31; Mk 13,20.22.27; Łk 18,7; Rz 8,29-33; Łk 11,7; 16,13; Ef 1,3-5.9-11; Kol 3,12; 1 Tes 1,4; 2 Tm 2,10; Tt 1,1; 1 P 1, 1-2; 2,9; 5,13; 2 P 1,10; 2 J 1,1; Ap 17,14).

Pojmowanie Kościoła jako communio praedestinatorum znalazło swoje odzwierciedlenie w księdze wyznaniowej Kościoła Ewangelicko-Reformowanego w Polsce, Katechizmie heidelberskim $(1563)^{8}$, w którym na pytanie 54: „Jak rozumiesz słowa:

7 Takie pojmowanie Kościoła napotykamy nie tylko u teologów reformowanych, ale także u wielu ich poprzedników, jak choćby Augustyna, Gottschalka, benedyktyna Honoriusza z Autun, Grzegorza z Rimini, Hugolina z Orvieto czy Jana Husa, por. R. Leszczyński (sr), Kłopoty z Mikołajem Rejem, s. 44-45.

8 W księgach wyznaniowych została streszczona nauka Kościołów ewangelicko-reformowanych. Ponieważ Kościoły reformowane w poszczególnych krajach są samodzielnymi organizacjami religijnymi, niepodlegającymi władzy synodów i konsystorzy innych (zagranicznych) Kościołów konfesji helweckiej, zatem każdy z nich posiada swój własny zbiór ksiąg wyznaniowych. W związku z tym „w łonie Kościołów reformowanych powstało około 60 ksiąg wyznaniowych. Większość z nich ma charakter lokalny. Nigdy nie powstał zwarty, powszechnie uznawany reformowany corpus doctrinae. Między poszczególnymi reformowanymi księgami wyznaniowymi występują większe różnice niż między luterańskimi. Nie odgrywają one też takiej roli jak w luteranizmie. Panuje generalna zasada, że księga wyznaniowa jest drogowskazem prowadzącym 
«wierzę w święty Kościół powszechny»?”, udzielona została następująca odpowiedź: „Słowami tymi wyrażam wiarę w to, że Syn Boży od początku aż do końca świata wybiera spośród całej ludzkości swój Kościół i przeznacza go do życia wiecznego; Duchem swoim i Słowem gromadzi go, chroni i utrzymuje w jedności

do Pisma św. [...] Możliwa jest weryfikacja treści zawartej w księgach wyznaniowych, gdyż wiele sformułowań powstało w określonej sytuacji historycznej [...]. Wszelka weryfikacja musi odbywać się jednak w oparciu o Słowo Boże jako jedyną normę wiary i życia" (K. Karski, Symbolika. Zarys wiedzy o Kościołach i wspólnotach chrześcijańskich, Warszawa 1994, s. 146). Pomimo że nie istnieje jeden ujednolicony kanon reformowanych ksiąg symbolicznych, to jednak niektóre $z$ owych ksiąg stały się popularne nie tylko w krajach, w których powstały, ale także poza ich granicami. Księgami takimi są na przykład Katechizm heidelberski (1563), który już w rok po swoim wydaniu został przetłumaczony na język polski, osiągając w naszym kraju olbrzymią popularność wśród ewangelików nurtu szwajcarskiego (por. R.M. Leszczyński (jr), Nauka ewangelicko-reformowana w polskojęzycznych katechizmach z XVI wieku, w: Ewangelicyzm reformowany w pierwszej Rzeczypospolitej. Dialog z Europq i wybory aksjologiczne w świetle literatury i piśmiennictwa XVI-XVII wieku, red. D. Chemperek, Warszawa 2015, s. 62) oraz II Konfesja helwecka (1566). Obydwa te dzieła uznawane są przez polski Kościół Ewangelicko-Reformowany za księgi wyznaniowe. Oprócz nich Kościół ten uznaje za księgę wyznaniową Konfesję sandomierskq̨ (1570), która powstała jako zmodyfikowane tłumaczenie na język polski II Konfesji helweckiej. W intencji polskich zwolenników ewangelicyzmu helweckiego wspomniana Konfesja miała stać się teologiczną podstawą Kościoła skupiającego naszych rodzimych luteranów, reformowanych i braci czeskich (stąd wzięły się wspomniane teologiczne modyfikacje tekstu II Konfesji helweckiej). O ile bracia czescy w pierwszej połowie XVII wieku utworzyli z ewangelikami reformowanymi wspólny Kościół, istniejący w Polsce do dnia dzisiejszego, przyjmując Konfesję sandomierska, o tyle luteranie woleli pozostać przy Konfesji augsburskiej, utrzymując na terenie Rzeczypospolitej odrębność swojej denominacji. Por. A. Tys, Początki wyznania ewangelicko-reformowanego w Rzeczypospolitej, w: Biblia brzeska - historia, język, teologia, red. R.M. Leszczyński (jr), Łódź 2013, s. 18, 22-23. 
prawdziwej wiary. Wierzę również, że i ja jestem tego Kościoła żywym członkiem i pozostanę nim na zawsze"

Jak widać, autorzy Katechizmu heidelberskiego, Kacper Olewian i Zachariasz Ursyn, za główną cechę Kościoła uznali to, iż jest on wspólnotą wybranych ${ }^{10}$. Takie postawienie sprawy powoduje, iż ewangelik reformowany uważa siebie za wybrańca Boga. Czy jednak poczucie wybrania nie napełnia wyznawcy ewangelicyzmu helweckiego pychą i przekonaniem o swojej wyższości nad innymi ludźmi? Zapewne mogłoby tak być, gdyby nie fakt, iż wraz z nauką o predestynacji ewangelik reformowany przyjmuje również tezę, że Bóg wybiera ludzi nie na podstawie ich zasług i pozytywnych przymiotów charakteru, ale wyłącznie z łaski, na którą w żaden sposób nie można sobie zasłużyć. Elekcja do wspólnoty Kościoła jest całkowicie wolnym aktem Bożej woli, niezdeterminowanym w najmniejszym stopniu postępowaniem człowieka ${ }^{11}$. Nie ma więc powodu, aby chełpić się przynależnością do społeczności wybranych przez Boga, o czym przypomina się ewangelikom konfesji helweckiej w kazaniach, traktatach teologicznych i pieśniach wykonywanych podczas nabożeństw.

9 Katechizm heidelberski, red. B. Stalh, Warszawa 1988, s. 39.

10 Również współcześnie teolodzy reformowani podkreślają, iż Kościół jest wspólnotą predestynowanych. W „Jednocie”, czyli głównym periodyku wydawanym przez Kościół Ewangelicko-Reformowany w RP, Bohdan Stanisławski twierdzi, że Kościół jest wspólnotą wybranych, „których Syn Boży - przez Ducha Świętego i Słowo Boże - powołuje od założenia świata i gromadzi w jedności wiary do życia wiecznego" (B. Stanisławski, Zarys nauki Kościoła Ewangelicko-Reformowanego, „Jednota" 31 (1973) 7-8, s. 6). Do zacytowanych powyżej słów Katechizmu heidelberskiego nawiązali w Porównaniu wyznań duchowni reformowani, śp. ks. Jerzy Stalh oraz śp. ks. Bogdan Tranda, według których „Kościół chrześcijański stanowią wszyscy wierzący, wybrani przez Jezusa Chrystusa od początku aż do końca świata i przeznaczeni do życia wiecznego. On Duchem swoim i Słowem gromadzi go, chroni i utrzymuje w jedności prawdziwej wiary (Ef 1, 4n)" (Porównanie wyznań, s. 41-42).

11 Por. Konfesja sandomierska 10, w: Prospectus fidei, red. S. Koroza, Łódź 2011, s. 140. 
Ponadto ewangelik reformowany nie może myśleć tylko o sobie i swoich współwyznawcach jako o wspólnocie wybranych, gdyż powinien żywić on nadzieję, że inni ludzie, nawet jeśli żyją oni w danej chwili z dala od Boga, również otrzymali łaskę wybrania. Nikogo z góry nie należy potępiać ani wykluczać ze wspólnoty wybranych ${ }^{12}$.

\section{Kościół (zbór) jako wspólnota świętych}

Odwieczny akt wybrania do wspólnoty Kościoła oznacza, iż ludzie powołani do niej otrzymują od Boga łaskę usprawiedliwienia, zbawienia i uświęcenia. Według Jana Kalwina i jego zwolenników, których nadal jest sporo w Kościołach reformowanych ${ }^{13}$, na skutek grzechu pierworodnego człowiek zerwał więź z Bogiem, odwrócił się od Niego, stając się niewolnikiem grzechu i szatana. Zatarty został w nim także obraz Stwórcy. W związku z tym wola człowieka stała się wolą niewolną, która sama z siebie nie jest w stanie zwrócić się ku Bogu i skierować ku życiu zgodnemu z Bożym Prawem ${ }^{14}$. Z upadku i alienacji wydobywa człowieka

12 Por. tamże, s. 141.

13 Utożsamianie ewangelicyzmu reformowanego z kalwinizmem jest daleko idącym uproszczeniem. Myśl Kalwina odegrała wprawdzie istotną rolę $\mathrm{w}$ trakcie kształtowania się doktryn ewangelicko-reformowanych, ale nie jest jedynym źródłem inspiracji wyznawców ewangelicyzmu nurtu helweckiego. Do dnia dzisiejszego wielu z nich bardziej ceni teologię Ulryka Zwingliego od nauk Kalwina, a liczni potomkowie braci czeskich mieszkający w Polsce przywiązani są bardziej do postaci Jana Husa niż do reformatora z Genewy, por. K. Karski, Symbolika, s. 145; R. Leszczyński (sr), Kłopoty z Mikołajem Rejem, s. 44; R.M. Leszczyński (jr), Nauka ewangelicko-reformowana w polskojęzycznych katechizmach z XVI wieku, s. 58; A. Tys, Poczqtki wyznania ewangelicko-reformowanego w Rzeczypospolitej, s. 12-15.

${ }_{14}$ Por. I. Calvinus, Institutio Christianae religionis, I, XV, 4-5.8, w: Ioannis Calvini opera selecta, vol. 3, lib. 1: De cognitione Dei Creatoris, red. P. Barth, G. Niesel, Monachii 1928. Zob. tłum. polskie: J. Kalwin, Istota 
łaska Boża, która inicjując w nim wiarę, wszczepia go w naturę doskonałego, bezgrzesznego drugiego Adama, Jezusa Chrystusa. Wybraniec dostępuje w ten sposób mistycznej unii z Nim. Za sprawą unio cum Christo i oczywiście związanej z nią wiary człowiek partycypuje w zasługach Chrystusa i skutkach Jego ofiary, a także odnowiony zostaje w nim obraz Boga ${ }^{15}$. W ten sposób otrzymuje usprawiedliwienie, zbawienie, uświęcenie i włączany jest w mistyczne ciało Syna Bożego, czyli we wspólnotę Jego wybrańców - Kościół, którego głową jest Jezus Chrystus (por. Ef 1,22-23; 4,15-16; 5,23; Kol 1,18) ${ }^{16}$.

Podążając za myślą Kalwina, który nazywany jest często teologiem uświęcenia ${ }^{17}$, ewangelik reformowany uważa, iż udziałem ludzi należących do zboru Chrystusowego staje się uświęcenie, polegające na nieustannym odnawianiu obrazu Boga w człowieku za sprawą działającego w Kościele Ducha Świętego (por. Kol 3,9-12) ${ }^{18}$. Dzięki Niemu oraz partycypacji wybrańców w doskonałym drugim Adamie chrześcijanie osiągają świętość.

religii chrześcijańskiej. Institutio christianae religionis, księga pierwsza, tłum. Zespół, Świętochłowice 2020, s. 277-285, 286-288. Zob. też tenże, Institutio Christianae religionis, II, III, 5, w: Ioannis Calvini opera selecta, vol. 3, lib. 2: De cognitione Dei Redemptoris, red. P. Barth, G. Niesel, Monachii 1928. Zob. na ten temat: R.M. Leszczyński (jr), Ojcowie Reformacji i filozoficzne wątki ich teologii, Warszawa 2010, s. 127-129.

Por. I Calvinus, Institutio Christianae religionis, III, XI, 2-4.11.23; III, I, 4; III, V, 8; III, XI, 10; III, II, 24.30.35, w: Ioannis Calvini opera selecta, vol. 4, lib. 3: De modo percipiendae Christi gratiae, red. P. Barth, G. Niesel, Monachii 1931. Zob. na ten temat: P. Jaskóła, Unio cum Christo w eschatologii Kalwina, w: Instaurare omnia cum Christo. O zbawieniu, teologii, dialogu i nadziei. Profesorowi Wacławowi Hryniewiczowi OMI w 70 rocznicę urodzin, red. P. Kantyka, Lublin 2006, s. 319-326.

16 Por. I. Calvinus, Institutio Christianae religionis, II, XVI, 5-6; II, XVII, 1-6; Konfesja sandomierska, 17, s. 157-158.

17 Por. M. Hintz, Wokót etyki protestanckiej. Początki po stronie reformowanej, w: Człowiek z Noyon. O Janie Kalwinie na łamach „Jednoty”, red. E. Jóźwiak, K. Urban, Warszawa 2009, s. 128.

18 Por. I. Calvinus, Institutio Christianae religionis , III, III, 9. 
Z tego powodu Kościół (zbór) określany jest jako congregatio sanctorum.

Warto podkreślić, że - zdaniem ewangelika konfesji helweckiej - człowiek nie osiąga świętości samotnie, za sprawą swych samodzielnych, indywidualnych starań, ale w zgromadzeniu wierzących, bierze się ona bowiem $\mathrm{z}$ ich uczestnictwa w świętości Chrystusa, będąc niezasłużonym darem dla ludzi. Zauważyć należy, że gdy apostoł Paweł pisał o świętych, nie miał na myśli poszczególnych cnotliwie żyjących osób, ale cały lokalny zbór, wspólnotę wierzących, czyli ludzi wszczepionych w świętość Jezusa Chrystusa, stanowiących Jego mistyczne ciało i świątynię Bożą (por. Rz 1,7; 8,27; 15,25-26.31; 16,2; 1 Kor 1,2; 3,16-17; 6,1-3; 14,33; 16,1.15.20; 2 Kor 1,1; 8,4; 9,1.12; 13,12; Ef 1,1.4.15.18; 2,19-21; 3,8.17-18; 4,11-12; 5,3.25-27; 6,18; Flp 1,1; 4,21-22; Kol 1,2.4.12.18-22; 3,12; 2 Tes 1,10; Tt 2,3; Flm 5,7). Ludzie ci stali się świętymi nie na mocy swoich indywidualnych zasług, ale dzięki uczestnictwu w naturze doskonałego drugiego Adama. To wybranie i powołanie do świętości sprawiło, iż Paweł nazywał adresatów swoich listów świętymi (por. Rz 1,7; Ef 1,4) pomimo ich wad i niedoskonałości, dostrzegalnych wyraźnie choćby w zborze korynckim (por. 1 Kor 3,3).

Czy jednak takie postawienie sprawy nie prowadzi do kwietyzmu? Otóż ewangelik konfesji helweckiej uważa, że nie ma takiego niebezpieczeństwa, bowiem choć źródło świętości ludzkiej znajduje się poza człowiekiem, a konkretnie w Chrystusie, to jednak osoby wybrane posiadają ją jak najbardziej realnie w związku ze swoją partycypacją w ludzkiej naturze Chrystusa. Unio cum Christo przemienia człowieka w nowe stworzenie, czyniąc członkiem Kościoła Chrystusowego. W ślad za tym pojawia się w człowieku pragnienie prowadzenia życia zgodnego z Bożą wolą, dążenia do cnoty i doskonałości (por. Gal 5,22-24) ${ }^{19}$. Ewangelik reformowany głosi więc tzw. syllogismus practicus, zgodnie

${ }_{19}$ Por. Katechizm heidelberski, pytanie 64, s. 43. 
z którym wiara i uczestnictwo w świętości Chrystusa przejawia się w owocach wydawanych przez wybranego, a więc w dobrych uczynkach i życiu oddanym Bogu ${ }^{20}$.

\section{Ewangelik reformowany w Kościele widzialnym i niewidzialnym}

Stwierdzono powyżej, że Kościół ma z natury dwoisty i dialektyczny charakter. Jednym z przejawów tej dwoistości jest fakt, iż funkcjonuje on w dwóch wymiarach: widzialnym i niewidzialnym. Istnieje więc Ecclesia visibilis i Ecclesia invisibilis. Obydwa te Kościoły przenikają się i splatają ze sobą, nie są jednak w pełni tożsame. Niewidzialny wymiar Kościoła wiąże się z faktem wybrania jego członków przez Boga, ostatecznie bowiem tylko On zna swoich wybranych, my zaś możemy jedynie domyślać się, że dana osoba należy do wspólnoty Bożych wybrańców, przypatrując się jej cnotliwym czynom i zewnętrznym przejawom religijności ${ }^{21}$. $Z$ drugiej strony Kościół niewidzialny przejawia się poprzez lokalne zbory, które tworzą widzialny Kościół powszechny. Ewangelik reformowany czuje więc przynależność i do niewidzialnego Kościoła wybranych, i do Kościoła widzialnego, zarówno powszechnego (dlatego określa się mianem katolika) ${ }^{22}$, jak i lokalnego.

${ }^{20}$ Por. K. Karski, Symbolika, s. 155-156; R.M. Leszczyński (jr), Nauka ewangelicko-reformowana w polskojęzycznych katechizmach z XVI wieku, s. 65-66.

${ }^{21}$ Por. Konfesja sandomierska, 17, s. 160.

22 Dla zwolenników szesnastowiecznej reformacji szwajcarskiej było jasne, że są katolikami, gdyż ich denominacja stanowi cząstkę Kościoła powszechnego, składającego się z różnych wyznań chrześcijańskich i lokalnych zborów, por. I. Winiarska, Słownictwo religijne polskiego kalwinizmu od XVI do XVIII wieku na tle terminologii katolickiej, Warszawa 2004, s. 203, 277; R.M. Leszczyński (jr), Mikołaj Rej wobec kryzysu antytrynitarnego, w: Mikołaj Rej i dziedzictwo reformacji w Polsce, red. B. Tondera, Kraków 2006, s. 69. 
Zwolennicy ewangelicyzmu helweckiego różnie pojmują relacje pomiędzy Kościołem widzialnym i Kościołem niewidzialnym. Niekiedy bardziej od tego pierwszego interesuje ich ten drugi, wielu z nich uważa jednak, że skoro wspólnota wybranych manifestuje swoją obecność w świecie poprzez Kościoły widzialne (poszczególne denominacje chrześcijańskie i zbory), zatem również one powinny być obiektem troski i zainteresowania wierzących ${ }^{23}$. Wydaje się, że we wczesnej fazie rozwoju eklezjologii reformowanej większy nacisk kładziono na kwestie związane z niewidzialnym aspektem istnienia Kościoła, atoli wraz z krzepnięciem Kościołów ewangelickich wyznania helweckiego coraz więcej uwagi poświęcano widzialnemu wymiarowi istnienia wspólnoty wierzących.

Owo przesunięcie akcentu z Kościoła niewidzialnego na widzialny widać już w teologii Kalwina. W pierwszym wydaniu Institutio Christianae religionis (1536) reformator przekonywał, iż prawdziwym Kościołem Chrystusa, w którym osiąga się zbawienie, nie są widzialne organizacje kościelne, ale niewidzialna wspólnota wybranych do zbawienia. Ów niewidzialny Kościół wybranych, złożony zarówno z ludzi, jak i z aniołów, jest świętym Kościołem katolickim, jedynym, niepodzielnym ciałem Chrystusa, gdyż nie ma kilku Kościołów Chrystusowych ${ }^{24}$. W liście skierowanym do kard. Jacopa Sadoleta teolog z Genewy przekonywał, że Kościół jest tam, gdzie panuje Chrystus, który jest jego głową, $\mathrm{z}$ tego powodu istnienie w Kościele widzialnego i hierarchicznie zorganizowanego episkopatu z papieżem na czele nie jest ko-

${ }^{23}$ Karl Barth postulował nawet, aby w ogóle zrezygnować z platońsko brzmiącego terminu Ecclesia invisibilis na rzecz podkreślania widzialnego wymiaru Kościoła, jednak pomysł Bartha nie przyjął się powszechnie wśród teologów reformowanych, por. K. Barth, Dogmatyka w zarysie, s. 133.

24 M. Friedrich, Kalwin a jedność Kościoła. Ekumeniczne znaczenie reformowanej Reformacji, tłum. E. Sojka, „Rocznik Teologiczny” 51 (2009) 1-2, s. 235; S. Piwko, Jan Kalwin. Życie i dzieło, Warszawa 1995, s. 121-122;

P. Jaskóła, Unio cum Christo w eschatologii Kalwina, s. 197. 
nieczne dla jego funkcjonowania i osiągnięcia zbawienia przez chrześcijan ${ }^{25}$. W późniejszych wydaniach Institutio Kalwin nadal rozróżniał Kościół widzialny i Kościół niewidzialny, twierdząc, że ten ostatni obejmuje wszystkich zbawionych, podczas gdy w widzialnym napotykamy także ludzi będących tylko z pozoru chrześcijanami. Reformator stopniowo jednak dowartościowywał Kościół widzialny, podkreślając, że osoby predestynowane należą do widzialnych zborów, słuchając w nich słowa Bożego oraz otrzymując sakramenty, dlatego należy pozostawać we wspólnocie z Kościołem widzialnym. To właśnie w nim Bóg daje swoją łaskę ludziom i przemawia do nich w swoim Słowie, dlatego też Kościół ten, przy wszystkich swoich niedoskonałościach, jest Matką wierzących. $Z$ tego powodu nulla salus extra ecclesiam ${ }^{26}$.

W Katechizmie heidelberskim (1563) nie mówi się o Kościele widzialnym ${ }^{27}$, rzecz ma się jednak inaczej w Konfesji sandomierskiej (1570). W artykule O świętym Powszechnym Kościele i o jedynej jego Głowie naucza się, że Kościół widzialny jest Kościołem Bożym, w którym od początku stworzenia Bóg powoływał ludzi do zbawienia i poznania prawdy. Kościół widzialny został więc ustanowiony przez Boga jako narzędzie zbawienia i jest tożsamy z Kościołem powszechnym. W związku z tym, iż istnieje tylko jedna głowa Kościoła, mianowicie Jezus Chrystus, istnieje też tylko jeden Kościół Boży, „który dlatego nazywa się powszechnym, ponieważ zawiera w sobie wszystkich chrześcijan po całym świecie rozrzuconych, do każdego wieku należący, nieograniczony żadnym szczególnym czasem ani miejscem" ${ }^{28}$. Ów widzialny Kościół powszechny składa się z widzialnych części, którymi są poszczególne denominacje chrześcijańskie wyznające wiarę w Chrystusa na całym świecie. Wspólnoty te różnią się często od siebie zwyczajami i teologią,

${ }^{25}$ L. Vischer, Koncepcja jedności Kościoła na podstawie listu Kalwina do kardynała Sadoleta, w: Człowiek z Noyon, s. 63.

26 S. Piwko, Jan Kalwin, s. 124nn.

${ }^{27}$ Katechizm heidelberski, pytanie 54, s. 39.

${ }^{28}$ Konfesja sandomierska, 17, s. 156. 
niektóre z nich zresztą błądzą w pewnych kwestiach doktrynalnych, jednak pomimo tego partycypują one w Kościele powszechnym, gdyż złączone są z nim wiarą w Jezusa Chrystusa ${ }^{29}$. Różnice w nauczaniu oraz powstające na ich tle niezgody pojawiały się już w czasach apostolskich, są one bowiem nieuchronnie wpisane w naturę widzialnego Kościoła. Pomimo wszystko Kościół powszechny istniał dalej, gdyż o jego jedności nie decydują ujednolicone doktryny i zuniformizowana liturgia, lecz trwanie we wspólnocie z głową Kościoła, tj. Jezusem Chrystusem ${ }^{30}$.

Konfesja sandomierska wyróżnia w Kościele powszechnym dwie grupy chrześcijan. Do pierwszej należą ludzie, którzy są autentycznie chrześcijanami. Są to osoby wybrane do zbawienia, uczestniczące w duchowych dobrach danych Kościołowi przez Chrystusa. Druga grupa tworzona jest przez pozornych chrześcijan, którzy tylko powierzchownie przyznają się do Chrystusa, albowiem nie doznali duchowego odrodzenia ${ }^{31}$. Chrześcijanie tacy nie dostąpią zbawienia, gdyż choć partycypują w Kościele powszechnym, to jednak nie są członkami Kościoła niewidzialnego ${ }^{32}$. Pamiętać wszakże należy, że Kościół niewidzialny istnieje w Kościele widzialnym, w tym sensie to w nim przekazywane jest więc ludziom zbawienie. Okazuje się, że poza widzialnym Kościołem powszechnym nie ma zbawienia, gdyż tylko w nim istnieje niewidzialny Kościół zbawionych ${ }^{33}$.

\section{Zakończenie}

Z powyższych rozważań wynika, że dla ewangelika reformowanego Kościół jest przede wszystkim wspólnotą ludzi wierzących

\footnotetext{
29 Tamże, s. 156-157.

30 Tamże, s. 158-159.

31 Tamże, s. 156.

32 Tamże, s. 160-161.

33 Tamże, s. 160.
} 
w Chrystusa, wybranych do niej przez Boga i uświęconych za sprawą partycypacji w świętości Syna Bożego. Poczucie wybrania nie napełnia jednak ewangelika konfesji helweckiej pychą, ponieważ zdaje on sobie sprawę $\mathrm{z}$ tego, że wybranie, zbawienie i uświęcenie są niezasłużonymi darami, które człowiek otrzymuje dzięki Bożej łasce. Należąc do niewidzialnego Kościoła wybranych, ewangelik reformowany troszczy się jednocześnie o swój zbór i widzialny Kościół powszechny. Uważa on, że wraz ze swoim zborem i rodziną Kościołów reformowanych jest częścią Kościoła powszechnego. Co ważne, nie stawia znaku równości pomiędzy Kościołem powszechnym a swoim wyznaniem, a tym bardziej pomiędzy niewidzialną wspólnotą wybranych a Kościołami reformowanymi, jest bowiem przekonany, że we wszystkich denominacjach chrześcijańskich odnaleźć można wybrańców Boga. Koncepcja jedynozbawczości jest obca ewangelikom wyznania helweckiego, dzięki czemu są oni na ogół otwarci na chrześcijan innych wyznań i traktują ich jako równorzędnych członków Kościoła powszechnego. Według prof. Karola Karskiego reformowana eklezjologia sprawiła, iż „Kościół Ewangelicko-Reformowany był od samego początku w szczególny sposób predestynowany do odegrania wiodącej roli w dążeniach ekumenicznych. Szczególną nośność ekumeniczną miał reformowany pogląd, że każdy Kościół jest partykularnym przejawem jednego powszechnego Kościoła Jezusa Chrystusa. [...] Tak więc otwarta postawa wobec innych wyznań oraz daleko idąca powściągliwość w ocenie zasad dogmatycznych głoszonych przez innych od samego początku uczyniły z członków Kościołów reformowanych aktywnych współpracowników we wszystkich nurtach ruchu ekumenicznego"34.

34 K. Karski, Symbolika, s. 162-163. 


\section{A reformed evangelical in Church community}

In a reformed evangelical's judgement Church is, most of all, a community of people who believe in Christ, chosen by God and sanctified owing to the participation in the human nature of Jesus Christ. According to a reformed evangelical, the predestination, salvation and sanctification are undeserved gifts of God's grace, not a result of human contribution. A reformed evangelical considers themselves a member of an invisible Church of the chosen ones, as well as the visible universal Church. A reformed evangelical does not consider the Evangelical Reformed Church and the universal Church as identical, because he believe there are people selected by God in all Christian faiths. Owing to that, he is open to Christians belonging to other churches and treat them as equally important members of the universal Church. 